IVICA MATIČEVIĆ

Chorwacka Akademia Nauk i Sztuk, Zagreb, Chorwacja

e-mail: ivica.maticevic@zg.t-com.hr

\title{
The Desert Called America: Poetry of Boris Maruna and American Popular Culture
}

\begin{abstract}
In the poetry of Boris Maruna (1940-2007), a Croatian modernist poet who is, together with Viktor Vida, considered the best Croatian emigrant poet, one can see the influences of American popular culture of the 1960s and 1970s. By living on three continents - Europe, South America, and North America - and having gained education in Los Angeles, Maruna incorporated into his poetic code some of the fundamental and typical determinants of American cultural and subcultural lifestyle. Fast food, television, film, rock/pop music, cars, freedom of sexual behavior... are some of the adopted forms of American culture that Maruna in his narrative poems both thematizes and advocates, but also questions in an extremely critical way. Irony, humor and strong satire represent the aesthetic aspects by which Maruna reveals the hypocritical, vain, and existential face of the United States of America of that period. On the other hand, like a distant Arcadia, there are landscapes and symbols of the homeland that he abandoned, and the desire to one day return into its physical spaces. However, even the so desired homeland cannot go without critical invectives and poetically ironic comments. Even then, Maruna's liberal "unadjusted" consciousness makes itself heard, outside all the dictates of expected behavior, thus completely isolating him from the matrix of Croatian emigration poets.
\end{abstract}

Keywords: modern Croatian poetry, popular culture, irony, Croatian emigrant poetry, sexual liberalism

Boris Maruna, a Croatian modernistic poet and essayist, was born in 1940 in Podprag, a village that does not exist anymore, on the southern slopes of Velebit. On the remnants of his stone birth house, there is now a memorial plate serving as a reminder that a great Croatian poet was born there. Maruna became a great poet in emigration. In 1960, together with his two brothers he escaped to Italy, then to Argentina, England, and the United States of America, followed by many other countries and parts of the world, some of which he simply passed through, 
as nothing more than an incidental yet fateful guest. ${ }^{1}$ A nomad of beauty, imprisoned within foreign borders but free in his dreams, Maruna dreamt of a change in the political system of his Croatian homeland, hoping for a fast return into a free and independent country - just like many artists and writers who after 1945 had to leave the country of their birth. The famous events that took place in Yugoslavia in 1990 opened for Maruna and his fellow literary and political brothers in emigration the gate of the new Croatia. Did the return finally mean the relief and the fulfillment of his exile dream, was it really easier to "love Croatia from the distance," to paraphrase the title of one of Maruna's poems, were his expectations excessive after all...? Let us follow our own path and stick to Maruna's destiny as one of the possible sources and paths for the determination and interpretation of the identity of Croatian writers in emigration, accepting the premise that the important part of Maruna's poetic code is connected with his adoption and critical relation towards the American popular culture that he became familiar with at its very source, in the United States of America.

\section{।}

As he did not accept Yugoslavia, in which it was not allowed to doubt the intellect of a certain Stipe Suvar and in which the association of resistance fighters made decisions on the salaries of members of academy, Boris Maruna accepted a certain fatalism of fate. That is precisely what the last lines of his poem entitled I am not the Man of the Party, say:

We are all here

As we cannot be anywhere else. ${ }^{2}$

Leaving Yugoslavia was completely logical for the twenty-year-old man who, had he stayed, would have been under the constant surveillance of authorities, as his Ustashi ancestors, apart from being re-ploughed in the second or third class of the common clay, ${ }^{3}$ became too heavy a burden for the personality of the man whose nature did not tolerate authorities or dogmas, or any ban on free expression of one's own opinion, and the restriction of public actions. For somebody whose intellectual and emotional habitus was under constant and expected imperative of doubt and verification by authorities, all meandering was out of the question.

1 See the text about Maruna's life and work written by Bruno Kragić: Maruna, Boris [in:] Hrvatska književna enciklopedija /Croatian Literary Encyclopedia, Zagreb, 2011, vol. 3 (Ma-R), p. 21-22.

2 All quotes from poems are given from the three books, selections of Maruna's poetry: Upute za pakleni stroj/Instructions for Time Bomb, ed. T. Maroević, Zagreb 1998, Tako je govorio Katul/Thus Spoke Catullus, Zagreb 2005, and Svijet koji znam / The World I Know, ed. B. Kragić, Zagreb 2015.

${ }^{3}$ In the poem Something like a testament Maruna/s lyric subject uses dark humor when mentioning his ancestors:

All my relatives rest on the cemetery in Miroševac

The second or thirds class in clay

And in the shade of an oak tree

Among the re-ploughed Ustashi.

Well done all of them! 
Thus, there was no place for the Augustinian "believe so that you may understand," even when it came to the educators and the strict professors at the Loyola University in Los Angeles, which Maruna, by no faults of his, attended from 1966 and where he got his master's degree in Anglo-American Literature. After England where the young Croatian emigrant writer, among other things, worked as an assistant at a hospital pathology ward taking care of, as he said, refined English dead bodies [as the English are indeed refined people, which is seen from the way they treat their umbrellas (a poem entitled It will be Raining over England Tonight)], his uncle from America invited him to study at the famous Californian university:

Luigi, a Sicilian guy, and I used to transport the sick people to operation rooms, and when somebody died we would transport the dead people to cold storage rooms. I have to admit that England is a tidy country and the people are polite. All these dead people were nicely washed and wrapped like mummies with a purple cross on their chest. The Sicilian man and I would grab them by their head and feet and throw them over. We endured for four months and were very conscientious workers. In England, I started working in Nova Hrvatska (a Croatian emigrant paper published in London, as of 1959), but as at a certain point the paper ran out of money, I had to go and work in the hospital. Thinking about the tidy country, I remember that like everybody else every day at 5 o'clock Luigi and I would get tea and those triangular sandwiches, and we would eat in the room with chief specialists and other staff members. This is that superior democracy. One day while we were sitting in that very common room, a nurse came to me and told me I had a telephone call from California. It was my uncle who told me that he was coming to England for Christmas. If I wanted to study, he would bring me the admission papers and next June I could come to LA. The English could not believe that an ordinary worker was going to study in America.

Maruna considered going to his uncle's America because, as he himself emphasized, he did not feel at all at fault for the American political system nor the American actions outside America's physical borders. By this, he thought primarily of the American undertakings in Vietnam at that time, but also of some later moves of the American foreign policy. In other words, America - and when he says America, he thinks only of the United States of America, not of South American countries, especially Argentina towards which he felt sincere gratitude and warmth ${ }^{4}$ - so, that precise America was for him and always remained nothing but a training ground and one of the links in the chain of his educational process in which he did not have to invest anything beside his persistent reading of books and passing exams, all in agreement with his benevolent uncle, a priest and an

4 "But, if we talk about the country I loved, then I have stayed faithful to Argentina my entire life. That is the first country that gave me its citizenship and its passport and to which I have always stayed correctly loyal. Even while I was living in America, I did not want to discard my Argentinian passport. Buenos Aires is a true European city that imitates Barcelona the same way Barcelona imitates Paris. If you search for Columbus passage in Barcelona, and then go to Buenos Aires, you will see that both avenues are almost on the same spot in relation to the sea and the river. In both cities, all houses stand on the colonnades. There are also some very similar streets and parks, and that is why Buenos Aires always seemed to me like the biggest European city in America. New York has it charm. It is the City, as the people from Dubrovnik would say. Still, it is the city of the new world, while Buenos Aires has the atmosphere not different from the one in Barcelona, Madrid, Paris or Prague. When you come there, you are home," ibid. 
University professor. Beside reading, there was also the added aspect of his failed marriage to his first wife, an American, who was, as he later admitted in his poem America, beside the obnoxious Yugoslavia, the most unpleasant thing in his entire life. That very fact, the trauma of divorce, together with a range of political, economic, and civilizational objections on the American reality, influenced his understanding of America as a desert, a place of loneliness, a figure of emptiness and anxiety, like a wrecked toponym that does not have its center and clearly marked walking directions, a place that encourages and demands a constant and uncertain search for a foothold and anchorage. Anyhow, beside the physical visible cornucopia, the American desert gave the feeling of thirst and hunger for political equality, for social equilibrium and limits in the recognition and acceptance of both one's own mistakes and other people's successes. After a definitive break up from his wife, when he, with tears in his eyes, left his minor daughter and set off for the desert called America, Maruna's lyrical subject in the above mentioned programmatic poem was swallowed not only by the emotional desert and feeling of anxiety caused by the sudden loneliness and loss of a family center, but also by the huge devouring space of plutocracy. It is the space where one cannot survive unless one can calculate, unless one knows one's multiplications and fractions, unless one, as an individual, is capable of becoming a strict and vicious pragmatist: again, some more instructions, again some dogmas, again the system in which one has to fit in elusively. Seemingly all of this is not there, seemingly everything is all right, and there is that feeling of freedom like nowhere in the world. Still, the mechanisms of financial dependence and imprisonment follow the man persistently, strategically as a spider, gradually and calmly waiting to captivate him into the false peace and prosperity. Thus, according to his own confession in one of his best essays, Maruna never felt gratitude towards America as he believed that he gave to America much more than it gave to him. After all, he duly paid all of his bills for tuition and overhead costs, and he eventually invested in America the most precious thing that a man can invest - his own child, that very same little girl whom he watched following him with her eyes from the balcony, through grids of freedom, while he started his car with tears in his eyes and left San Pedro to go to the unknown empire of the seething sand:

When I stepped on the street again

The first yellow lights were already lit

At the San Pedro harbor

And on anchored ships

And I looked up

And saw our little girl watching me benumbed

Through the balcony grids, and I waived to her

And entering the car I thought

I should come back because of her

And tell to my wife: Life was always

A dirty school writing board; let's clean it, baby,

And start again.

But I did not do anything

Just turned on the ignition key, shifted into gear

And with tears in my eyes, I admit, 
With tears in my eyes I started off

Through the first dust

Through the desert called America. ${ }^{5}$

Approximately at the same time Maruna also wrote his essay Gratitude and America, first published in Hrvatska revija, ${ }^{6}$ in which he expressed his decisive disagreement with the American way of life, his contempt towards the "desertlike" everyday life experience in which human rights are not respected and every man is just a physical economic fact, adjusted and conditioned by the laws of market and consumption:

nobody gives me anything, only what I earn or have earned myself. Therefore, I do not owe anybody anything and I have no valid reasons to be grateful to anybody. Moreover, I easily refuse any idea that I personally might be responsible for the system in the United States. Like millions of other people, I am only coping in the given circumstances. (...) On the other hand, no matter what my appetites, basically modest ones, might be, they are not of such nature that I could not satisfy them anywhere in Europe. As I am, above all, the man of agora, America is not and it cannot be a promised land that I would recommend or that I, with a clear consciousness, might recommend. America that I live in and that I know always multiplies when buying and always divides when selling, and, thus, as far as I am considered, it asks for too big a price for what it offers. For me, in order to live and write the way I want to, I do not need the United States of America, nor are they the most fruitful ground for such existence. (...) In accordance with the above said, the same as all people, I also owe something, including gratitude, but exclusively to my family and to my people. However, to America, I do not owe anything. (...) Anyhow, in the humus of American soil there is nothing that would make a Croatian, Italian, Polish, German or Irish, a better man. In my case, my life went into such a direction that I have more acquaintances and faithful friends among that people than among my own. Besides, I invested in that people the most that a man can possibly invest: my own child. Thus, I do not and cannot wish to the American people anything that I would not wish for the Croatian people or for my own child. But, America will in vain (even if that were important) expect from me any kind of gratitude. There is no place for such a thing in my heart. ${ }^{?}$

As much as he does not idealize the American sense of freedom and its life program in which, contrary to expectations, the terror of profit and propaganda rules, and where there is no equality and justice for all, where human rights are a matter of perspective and not of beliefs or positive laws, he also rejected every aspect of pathetic nostalgia and lamentation for the Mother Croatia. Irony is a successful, tactical survival kit and a tool for reassessment of the vain and pathetic patriotic enthusiasm. However, his love and desire for the lost homeland and the

5 A poem America was published in the poetry collection Ograničenja / Limitations from the year 1986.

6 "Hrvatska revija" 1987, no. 2, p. 278-293.

7 A quote according to the abovementioned essay published in Maruna's collection of essays entitled Što je čuvalo nadu / What was Keeping the Hope, Zagreb 2008, p. 140-149. 
mythical land of his forefathers is never questionable. ${ }^{8}$ That is why it is possible that he, as a free citizen of the world, although with a poor bank account and an ability to seduce chambermaids and all kinds of hermanitas (i.e. little sisters, as he used to affectionately call his bed companions, Marx is Dead), repeatedly proclaims himself a true Croatian terrorist of the post-war generation (When I was a Croatian Terrorist; I don't Envy Croatian Poets) and a fucking Ustashi (Mai più) who, in accordance with notorious instructions, works on his spiritual time bomb for sabotaging the false freedom and rotten American democracy, and the abhorrent and egalitarian Yugoslav community of people and nations, to whose greatest sons he unreluctantly - to every one in particular and to all collectively - says "f--- you" (Instructions for Time bomb; I Speak up Loudly). His imaginary time bomb, a poetic bomb, is the primary tool for personal liberation from all kinds of smaller or bigger admixtures and acquisitions of the merry sons of a bitch who are not and do not have to be only the local Croatian members of the Yugoslav secret service $(U d b a s ̌ i),{ }^{9}$ but are also the centers of post-industrial power, with political and bank lobbies creating the American and also, through global media and financial strategy, the global reality. America is a direct level of "un-fairytale" life, and Croatia is the desired country. America is an accidency, a prerequisite and a necessary evil for survival, and Croatia is the substance of his humanity, meaning a poetic "talking out loud" that leaves behind a basic love for his Croatian homeland without tunes of nostalgic sobbing, with an ironic coating as a meaningful and significant substrate and a loose algorithm of fractioned syntactic units. This seems to be felt the most in the afore mentioned poem Something Like a Testament, dedicated to Dubravko Horvatić. He, along with Šoljan, Slamnig, Matoš, Ujević and Dragojević, was in Maruna's pantheon of recognized Croatian poets, those with no moustache and not waving their poetic lamb and spring onion (Programmatic Poem; The Croats are Getting on my Nerves). In the above mentioned poem the lyric subject requests that when he dies he should be buried among his forefathers, Croatian shepherds, without a coffin, among the stones on the Velebit mountain so that he can watch the sea from its top as he is, he must say, fed up with the world progress of which he has seen too much so far and which he has met so many times during his multicontinental wanderings, as he has had enough of material abundance in all kinds of regulated and promised lands where allegedly it's all milk and honey. Precisely because all of this is not true, because it is just an illusion and a lie, only spectacle, propaganda and carnival imposed by the media, the lyric subject desires the space of unspoiled nature, the dawn of humanity, Consolation of Hair and Smell of Allecost, the keystone from his Velebit, the transformation of the American desert of freedom into the desert of homeland

8 On the fundamental importance of irony for Maruna's lyrics, see: B. Kragić, Pjesnik kao "Eiron”" poezija Borisa Marune / A Poet like 'Eiron'- Poetry of Boris Maruna [in:] Dani hvarskoga kazališta. Playing and Festivity in Croatian Literature and Theater. Vol. 31, Zagreb-Split 2005, p. 416-425.

9 State Security Administration (UDBA or UDSA), was the secret police organization of Yugoslavia. Best known at all times simply by the acronym UDBA, in its latter decades it was composed of six semi-independent secret police organizations - one for each of the six Yugoslav federal republics - coordinated by the central federal office. 
stone paradise. Maybe that is why Boris Maruna became a poet - to become isolated from the visible, physical world, to destroy it by his poetic time bomb and to win over its ruins the space of Velebit for his inner peace. Either in Croatia after returning from the rambled world, either later on in Chile as an ambassador, after the rambled Croatia, it does not matter. Partly tacitly, almost as a mere coincidence, as it often happens, his poetic wish seems to have been met: a memorial plate dedicated to Boris Maruna was placed several years ago on the ruins of his birth house at the foot of Velebit, on the southern slopes in Podprag, facing sea...:

And let me rest among the Illyrians

Romans and ancient Croatians;

Let me listen to Velebit

And watch the sea.

After I have seen a lot

Of progress in the world

To finally be a little happy:

To be among my own people.

A shepherd among shepherds.

\section{(Something Like a Testament)}

The aspect of American desert of freedom is observed mostly from the geographic region of Los Angeles, the second largest city in the USA, from the belonging topography of its suburbs and famous beaches about which he repeatedly writes in his narrative lines: Hermosa Beach, Manhattan Beach, Venice Beach, Santa Monica, San Pedro Harbor... The 1960s were marked by the buoyancy of American popular culture, and the City of Angels is one of its centers. ${ }^{10}$ By getting to know himself and the world at the very source of the globally most influential cultural matrix, Maruna committed himself to the determined non-compliance, as a part of beliefs and understandings that, as we partially saw earlier in his essay Gratitude and America, always alienated him from American illusions. Moreover:

In 1966, after a little bit more than 5 and a half years, with my changeable fortunes, I entered the United States over night, through doors wide open. Like everything else in my life, that fact had both its undoubted advantages and certain indisputable disadvantages. While other Croatian students, mostly small in numbers, most often studied under difficult conditions, leaving behind the sweat and an endless red line of commercial loans, for me it

10 On the most important events and phenomena that marked the American popular culture in the 1960s and 1970s, see some comprehensive books like: Sharon Monteith, American Culture in the 1960s, Edinburgh 2008, or Michael Burgan, Popular Culture: 1960-1979. From Soul and Psychedelia to Punk and Pop Art, Chicago 2013. When we talk about theoretic approaches in the interpretation of the phenomena of popular culture, the works by John Fiske (Understanding Popular Culture, London 1991), John Storey (Inventing Popular Culture. From Folklore to Globalization, Blackwell Publishing, Malden et al., 2003) and Dominic Strinati (An Introduction to Theories of Popular Culture, London 2004), are unavoidable. A very useful and comprehensive paper on the theoretical approaches to popular culture is the one written by Danijel Labaš and Maja Mihovilović, Masovni mediji i semiotika popularne kulture / Mass Media and Semiotics of Popular Culture, "Kroatologija" 2011, vol. 2, no. 1, p. 95-122. Besides, the doctoral thesis by Tatjana Ileš (The 1960s in Croatian Literature and Culture, Osijek 2013) is very instructive and stimulating for the study of popular culture in Croatian prose literature of the 1960s. 
took very long to figure out that in Los Angeles, along with Palos Verdes, Pacific Palisades, Beverly Hills, and the marinas, there is also something called Watts. I did not have time for that part of the city, and I found out about it only after the black people had set it on fire. Among those undoubted advantages is the fact that I, unlike unprivileged Croatian students, was from the very first moment able to see America not only during gala dinners but also undressed after them. I was not impressed. However, I also saw the United States a year and a half earlier... At that time, I was impressed by the New York skyscrapers, Californian roads and Hollywood women who were indeed offering more than a celluloid dream. However, these are the things that, the same as toys in children's hands, cannot maintain the tension needed to keep a man impressed for a longer period of time. It is also not accidental that in the United States nobody semantically differentiates civilization and culture, in the same way that nobody differentiates country and nation. ${ }^{11}$

A poetic reevaluation of popular American icons - from art, music, film, food products, and frolicsome habits and profligate meanders of American lifestyle most definitely depended on the concrete life, on tangible goods that in Maruna's case, thanks to his uncle, were relatively safe, and on the spiritual climate and experiences of the student generation in the dynamic environment of American social, political, and cultural events of the 1960s and 1970s. Due to Maruna's rebellious and critical attitudes towards the behavior and actions of Croatian emigrant circles and groups, his Croatian emigrant brothers did by no means make his life easier and more careless. Specifically, he was told that they ,had every right to expect more from you - you should have been more combative, written more emotional poems." These were their convenient advices that Boris "embedded in his next poem" like all the other garbage that the Croats had left behind, all around the continents. In his famous poem The Croats are getting on my Nerves, published in his poetry book I Speak out Loud from the year 1972, we meet the exemplary Maruna, a critical poet who, above all, beside his abandoned homeland, loves and appreciates his own secured freedom and integrity ("You can screw poetry, but not me"). He shares his dream about the Croatian freedom with hundreds of refugees or exiled people, but he does not even think, not in the name of any patriotism, about rejecting the criticism of primitive and uncivilized behavior, the unfounded objections to his consciousness or behavior in relation to the expected average of any pathetic Croatian emigrant. Under the context of events from the Croatian history in the 1990 s, in the time when he wrote that poem, "it was not Croatia that was getting on the nerves of Maruna, but the Croats who believed that the dream about the country is the final solution that absolves us of all duties, that the country is our goal and that the country itself can justify all the mistakes and malpractice of dishonest individuals" $" 12$.

11 Zahvalnost i Amerika/Gratitude and America, in the abovementioned book, p. 144/145.

12 S.P. Novak, Od srca is razumom / From Heart and with Reason [in:] B. Maruna, Što je čuvalo nadu / What was Keeping the Hope, the above stated book, p. 10. In his poem A Fight against Ghosts Maruna also thematizes his, this time quiet and intimate settling of accounts with them, with the entire group of imaginary Croatian notables, the ghosts warning him that his behavior is not nationally conscious enough, that he should be more considerate of the Croatian tradition, that he should shoulder the burden harder for the Croatian thing in order to show in a more emphasized manner his feeling of belonging, etc. This time the response of the poetic subject, unlike the response and intonation in his poem The Croats are getting on my nerves, that was written after A fight against ghosts, is not verbally 
Not inclined to nostalgia and pathetic tirades on the lost stone, tree, brook, snake, drywall, and the highly held sabre of Ban Josip Jelačić, and having adopted at the very source the existential cynicism and rebelliousness of his friend Charles Bukowski, developing ever more readily "the behavioral version of adaptability" 13 in the enormous epic space that America is, and that revealed itself to him much better when he perceived it in a coat freed from all pathos and through the optics of a "modern political picaro who replaced his homeland by the world"14, Maruna started to also imbed the elements of American popular culture in which he was developing both as a man and a poet into his subsequent poems, just like the leftover garbage after the lamb feast of the Croats. If we accept the direction of analysis that would suggest that the so called "garbage" represents in fact the provisions for the journey of a cautious and keen collector of experiences who in that way enriches his treasury of knowledge about the man and the world, then we would also see Maruna as a human recycling machine, a poet in a dynamic movement, who renews and regenerates over and over again his aggregate of knowledge and critical opinions embedded in his poems. This is not a spin around mythicized caryatides sadly tolerating his patriotic pain, but an active chronicler of the world who can and will be counted on, in the concrete national sense, as long as he is allowed to honestly say everything he thinks, with no limitations, and out loud. The elements/motives of American popular culture are the traces of the context and facts within which one used to grow up and out of which developed a certain dose of criticism, irony, grotesqueness, and dark humor of Maruna's lyric subject. Behind the elements of physical reality, set up into free, casual, conversational narrative verses and rhythm of speech, there is a poetic desire in sight, a desire for freedom, love, a dear one, a brother, a homeland, and care for the entire world. American popular culture with all its agents is a physical prop storage through which the light of poetic messages and lessons is refracted, a practical inventory of reality open to recognition and rejection, all in line with the poet's understanding of the world. A devotee of spontaneity, directness and literalness in the representation of that world, Maruna uses the elements of American popular culture exactly as such - used, consumable, stone artefacts. It is in fact the rough archeology of everyday life, delving among the symbols of the consumer society in which its human subjects are also being consumed. Splinters of the system, fragments of the broken whole, an individualized and freed from pathos experience of the world - the world externally and spiritually marked by sex, ad-

direct and harsh, ironic and satiric. Finally, after the disagreement and the initial peaceful difference of opinion, both the poetic subject and the voices of ghosts of the Croatian ancestors and tradition remain together in mourning for the abandoned homeland. They were all on the same side, united in their hope of return, but each with his own feeling and way of putting up with the emigrant destiny. Maruna never gave in to the collective hysteria and obligatory algorithm of nostalgia, to the joint launching of slogans and to futile lamentation. I think we can correctly conclude that he was disgusted by that.

13 T. Maroević, Prostranstva i tjesnaci Borisa Marune / Widths and Narrow Passages of Boris Maruna [in:] B. Maruna, Upute za pakleni stroj/Instructions for Time Bomb, the above stated book, p. 243-257.

14 Z. Mrkonjić, Volio ju izdaleka, boljela ga izbliza. Sjećanje na Borisa Marunu / He Loved it from Afar, it Hurt him from Near. A Memory of Boris Maruna, "Vijenac" 2007, June, no. 347. 
vertisements, fast food, rock music, television, radio, film, comic books... In the elements/motives of American popular culture one should not observe and seek for a special spiritual etymon - most frequently Maruna refers to those elements as to completely ordinary landmarks of American everyday life (motives from the street, television, magazine covers...) for which he shows no interest at all. Beside sporadically mentioning them in his poems, he has no additional emotion for them and he does not base on them any important poetic energy and credibility, as they are only an occasional decorative drapery and an essential part of the current iconography of American reality (hamburger, marihuana, LSD, Coca-Cola, Frank Sinatra, Elvis Presley, Bob Dylan, Playboy, movie stars on Beverly Hills, Sunset Blvd., IBM, Jackson Pollock, Allan Ginsberg, Andy Warhol...). However, sometimes, when he more considerably accepts them, he sees in them the traces of freedom, or at least the possibility for the liberation of his adventurous, ludic, and humorously marked spirit. So, what is it all about? Which aspect from the wide and dynamic package of pop culture was, after all, especially beloved by Maruna?

III

As every other emigrant, by adopting a temporary formula called "I live here, and I dream of Croatia," Maruna was at a certain point of time taken by the nomadic fate to the USA. Let us remember the line saying "we are now here as we cannot be anywhere else." This however did not mean at all that he had to be uncritically grateful for that fact, ready to accept the system of the world and society that he lived in without any complaints, under the influence of somebody's external or self-proclaimed censorship, under the aegis of a poor and agonized Croatian emigrant from a certain third world country. And, least of all, it did not mean that he could not in large quantities take advantage of certain hedonistic results of the American rebellious and liberal behavior brought in one aspect of its phenomenon, as a successor of the avant-garde mentality of anti-establishment, by the social dynamics of the subversive 1960s and popular culture. That was the sex revolution (the sexual liberalism of baby boomers also influenced certain offsets of popular culture - the increase and growth of individualism on the public social scene, the culture of openness and dialogue, and most importantly the invention of the contraceptive pill - these were important psychological and physical events and the drivers of social changes for the young generation in the 1960s and 1970s). ${ }^{15}$ In any case, it so happened that the uninhibited reaching of climax of a certain practice was especially appealing to the young poet: rebelliousness, critical consciousness, and a certain dose of nonadjustability in its orgasmic action, in the literal sense of the world. It is precisely the statements and expressions, images and scenes, more or less concrete and allusive, of intercourses of all forms and types of free sexual behavior, that impregnate Maruna's poetry. The playfulness of his libido coming out primarily from the author's ludic

15 See about that: D. Allyn, Make Love, not War. The Sexual Revolution. An Unfettered History, Boston 2000. 
and liberated consciousness and his fantasy about what this should look like, and partly of course out of the practice itself, along with some expected exaggerations about the number and the size, transformed the critic of the predatory capitalism and post-Hollywood comprehension of reality as a spectacle and a media postcard in which everybody feels good and bad at the same time - according to the development of the planned manipulation - into the measure of a man of a clear conscience, or at least into a dignified cynic who completely advocated the liberation of human nature from all distraints and forced standards of former times. Sexual motives (intimate body parts, sexual intercourse, sex positions, subordination of one sex to another, sexual abuse, sex appeal in general...), a humorous playing with the elements of corporality in which the lyric subject figured as a god of sex and a mannerly seducer in jeans on Californian and other boulevards and beaches (not to mention bars, whisky, martini, prostitutes...) were the poetic code of reevaluating the imperfect reality. A decent Croatian student of the Jesuit University readily accepted such a liberated America. At least as his penance for acquiring additional knowledge on the man and the world that he will of course, as everything else, "imbed into his next poem." According to the mandatory curriculum of Boris Maruna, a certain bodily hedonism was recommended, no matter how willing the spirit was. In the formal sense, the topics of love and sex were represented in a wide range, from concrete images to allusive traces:

Out in the morning sun someone was winning the game

One could hear laughter and the host's sadistic voice saying: Forty Love

At the same time she bit the pillow to suppress her scream

While I was standing above her as a true Greek god, young and healthy

But, as I am not Ivan Slamnig, I couldn't take it

And I came.

(Programmatic Poem)

\author{
I have a soft heart I took her \\ from the street and washed \\ I bought her new boots \\ and took her in her mini skirt to the museum \\ and the theater to see Rembrandt \\ and Old Vic Co. \\ and to gain some basic culture \\ I was also taking her every day \\ Up and down \\ from front and from behind Take her \\ as you please: she is awfully \\ talented \\ In every respect we were both \\ very satisfied \\ (I Saw the Future) \\ She introduced herself as a daughter \\ Of a Ukrainian cloth dealer, \\ A Jew from Brooklyn,
}


An intellectual type:

She had a Ph.D. and allegedly the biggest breasts

North of Grand Canyon

I worked on them all night long

I don't remember making sparks fly.

(...)

At parting she left me

Half a bottle of Bahamian rum, several

Progressive magazines a few months old

The original edition of

Macdonald's book The Root is Man

And a certain sexually transmitted disease

With which I regularly went to the beach

For some twenty days

And I passed it on in the meantime

Like Tito's

Baton

(The New Left)

This is what my wife looks like: in her tree the juices

Grow high, the dialectic of her touch

Is never repeated

If you are in a bad mood

You cannot have one more drink, you cannot

Break a good piece of furniture

You cannot just push her

Aside

By her smile of cheerfulness

In big letters of Californian ranches

She perseveringly writes above her door:

Boris Maruna is allowed to enter any time.

\section{(Love)}

Love adventures and sex games, playing with his own imagination and the imagination of his readers, exhausted almost completely Maruna's consideration of American popular culture as a stimulating treasury of motives for a poetic conquest. One might additionally mention Maruna's inclination towards the car as a means and symbol of psychological escape. On the road, in his very own used car, the poetic subject felt freedom and authority, the possibility to withdraw into himself and into his thoughts. And, in the interlacing of images caused by a faster or slower drive, he also felt the possibility of a real or imaginary fight with the others (as representatives of the world) who at that moment could not spite him (America; Pacific Coast Highway). All he had to do was shift into gear and press the gas pedal:

Today while I was driving along the Golden State Freeway

Two important things happened to me 
Out of the blue some woman showed me

The forearm jerk using her middle finger

At the same time I heard a rumbling voice

Warning me

I thought that was my inner voice

But as it approached I could well discern

That it was the voice of a higher being

And that voice of a higher being

Told me to cross the four lanes immediately

And to turn to the west at the next exit

To urinate on the gas station

And maybe drink coffee and eat a hamburger

At the Bob's Big Boy restaurant

I replied something that when put on paper

At a scientific convention might surprise

The entire modern theology

And I waived wearily to the woman

Put down the right window and yelled goodheartedly:

You suck it, honey, I am too old

To switch sides now.

\section{(La vita nuova)}

Still, even the imperfect America with the whole range of social and political problems and unmeasurable hypocrisy in the implementation of the so called democratic laws, as it was in the times when Maruna used to go from one American door to another, was still better than the most perfect Yugoslavia (from the above stated poem Something Like a Testament: But if you wish good to yourselves/If you wish good to your children/-In one way or another/In any way-/ for God's sake,/First get rid of Yugoslavia!'). ${ }^{16}$ Boris Maruna knew better than anybody else what it is like to live in the American desert of freedom and how to survive in it, by taking what suited him, respecting his own choices, and without complying to splinters and any kind of imposed icons, were these Donald Duck in the past or Donald Trump today - it does not matter:

Lesson: We should pity the Americans

as we pity ourselves They are not different from us

they are only full of spinach and strength

so when they want something

following the example of their president

they do it.

And it works.

And sometimes it does not work.

(Being There)

16 Maruna had excellent knowledge of political, economic and cultural circumstances in Yugoslavia and Croatia while he still lived in emigration and he wrote about them in a convincing and argumented manner. This can be seen from the essays published from the 1960s until the end of 1980s in Hrvatska revija (the above-mentioned book Što je čuvalo nadu / What was Keeping the Hope). 
Finally, there remains the isolated destiny of a conditionally unadjusted and wild poet as the specific image of a Croatian emigrant poetic being, outside the usual frames: he loves his homeland through memory, desire, comfort, and poetry. He feeds himself with critical non-consenting to the so-called financial security and the humanistic illusions of the brave new world, he never forgets the seducing possibilities and the beauty of his mother tongue, and in the same time he despises pathetic nostalgia and the creation of new dogmas of awe and adoration of the homeland from abroad. Especially when the orange color of homeland happiness starts transforming into the new grey color of the copied American desert. That is why Maruna is not a typical emigrant poet, a choir singer, the expected poetic and human average that, with his head bowed, is uncritically grateful to the country in which he once lived and in which he got his education. He is also open-handed when he talks about the weaknesses and the passions of Croatia, its habits and customs, even when he was passing the borders of countries on three different continents, and especially not when he returned to the so much desired Croatian freedom marked, among other things, by the terror of Croatian politicians and its belonging political-banking elite, political hypocrisy, Croatianhood only for gain, bribe, corruption, wealth gained over night, an amusement park of the "merry sons of a bitch". ${ }^{17}$ Much less than to his fellow travelers-emigrants, contemporaries exiled from Croatia after 1945, by its human habitus, id est the basic perception of the man and the world, his critical relation and intellectual behavior, Maruna is much more like another Croatian emigrant poet - Antun Gustav Matoš. Speaking on the occasion of the fiftieth anniversary of Matoš' death, Maruna seemed to have talked about his own emigration destiny and his own importance:

\footnotetext{
Mostly lonely and scattered all around as carnival confetti, Matoš was discovering new horizons and breaking the poor relations of our $19^{\text {th }}$ century with the stale stable of the black and yellow crown and the crown of St. Stephen, trumpeting and begging from the Seine our 'dear contemporaries' who worked as stable-men all around, and did not manage to free themselves from their servility and finish once for all with all kinds of ingratiation and political opportunism (which, perfectly apathetically, we still pay tribute to) (...) In Croatian literature there are few writers, and even when those are writers whose opus would never endure outside the narrow borders of Croatia, who would in such extent depend on the soil and people from which they grew, as it is the case with Matoš. (...) His fate is inseparably connected with the destiny of his Croatian people: and only in that dependence he will persist. ${ }^{18}$
}

17 See Maruna's editorials - essays in Vijenac from September 1995 until December 1998, collected in the above-mentioned book Što je čuvalo nadu / What was Keeping the Hope.

18 B. Maruna, Antun Gustav Matoš (1873-1914), Što je čuvalo nadu/What was Keeping the Hope, p. 15-18 (italics by the author). First published in: "Hrvatska revija", no. 2-3, Buenos Aires 1964, p. 242-244. 


\section{Bibliography}

Allyn D., Make Love, not War. The Sexual Revolution. An Unfettered History, Boston 2000.

Burgan M., Popular Culture: 1960-1979. From Soul and Psychedelia to Punk and Pop Art, Chicago 2013.

Fiske J., Understanding Popular Culture, London 1991.

Ileš T., Šezdesete u hrvatskoj književnosti i kulturi, Osijek 2013.

Ileš T., The 1960s in Croatian Literature and Culture, Osijek 2013.

Kragić B., Maruna, Boris [in:] Hrvatska književna enciklopedija /Croatian Literary Encyclopedia, Zagreb 2011, vol. 3 (Ma-R), p. 21-22.

Kragić B., Pjesnik kao “Eiron” - poezija Borisa Marune [in:] Dani hvarskoga kazališta. Igra i svečanost u hrvatskoj književnosti i kazalištu. Knj. 31, Zagreb-Split 2005.

Labaš D., Mihovilović M., Masovni mediji i semiotika popularne kulture, "Kroatologija" 2011, vol. 2, no. 1.

Maroević T., Prostranstva i tjesnaci Borisa Marune [in:] B. Maruna, Upute za pakleni stroj, Zagreb 1998.

Maruna B., Antun Gustav Matoš (1873-1914), Što je čuvalo nadu, "Hrvatska revija", no. 2-3, Buenos Aires 1964, p. 242-244.

Maruna B., Ovako je govorio Katul, Zagreb 2005.

Maruna B., Što je čuvalo nadu. Eseji i kritike, Zagreb 2008.

Maruna B., Svijet koji znam, ed. B. Kragić, Zagreb 2015.

Maruna B., Tako je govorio Katul/Thus Spoke Catullus, Zagreb 2005.

Maruna B., Upute za pakleni stroj, ed. T. Maroević, Zagreb 1998.

Monteith S., American Culture in the 1960s, Edinburgh 2008.

Mrkonjić Z., Volio ju izdaleka, boljela ga izbliza. Sjećanje na Borisa Marunu, "Vijenac" 2007, no. 347, 21.VI.

Novak S.P., Od srca i s razumom [in:] B. Maruna, Što je čuvalo nadu. Eseji i kritike, Zagreb 2008.

Storey J., Inventing Popular Culture. From Folklore to Globalization, Malden 2003.

Strinati D., An Introduction to Theories of Popular Culture, London 2004. 